\title{
SOSIAALIPOLITIIKAN SOMMITELMIA ENNEN JA NYT
}

\section{Pääkirjoitus}

\section{of a I U \&}

Tänä syksynä tulee kuluneeksi 60 vuotta siitä, kun Pekka Kuusen kirjoittama ja alun alkaen Sosiaalipoliittisen yhdistyksen julkaisema teos 60-luvun sosiaalipolitiikka ilmestyi.Vuonna 1957 Alkoholiliikkeen jakelutoimen johtajana toiminut Kuusi sai yhdistykseltä toimeksiannon yleistajuisen sosiaalipolitiikan kokonaisohjelman laatimiseksi. Tehtävän toteuttamista avittivat muun muassa Huoltaja-säätiön tarkoitukseen myöntämä rahoitus ja lukuisa joukko asiantuntijoita.

Teoksen julkaisu osui 1960-luvulla tilanteeseen, jossa Suomi oli suuren murroksen kynnyksellä: suuret ikäluokat olivat astumassa työelämään, Suomi kansainvälistyi ja kilpailu kiristyi, mutta yhteiskunnan asenteet ja rakenteet - myös sosiaalipolitiikan näyttivät auttamattoman vanhakantaisilta (Tuomioja 2002). Modernisaation käsikirjana Kuusen teos synnytti heti julkaisunsa jälkeen laajaa julkista keskustelua. Esimerkiksi eduskunnan pöytäkirjoista löytyy 1960-70-luvuilta lukuisia viittauksia Kuusen teokseen. Riihisen (2009) mukaan aika oli Kuusen teoksessa esitetyille ajatuksille, kuten kasautuvan kasvun idealle, tuolloin otollinen. Toki teosta, etenkin sen materialistista ihmiskäsitystä, myös arvosteltiin. Vaikkei Kuusen hahmottelemaa ohjelmaa koskaan toimeenpantukaan täysimittaisena, on teos kiistatta osa ajattelutapojen muutosprosessia ja siirtymää kohti universalistista hyvinvointiajattelua, jossa kansalaisen paras nähtiin sosiaalipolitiikan viimekätisenä tavoitteena. Muutosta vauhditti osaltaan raju rakennemuutos, jossa sosiaalipolitiikan kytkös talouspolitiikkaan tiivistyi agraarisen ajattelun väistyessä ja palkansaajien työvoimaosuuden kasvaessa. Jälkikäteen katsottuna Kuusen teoksen laajempi merkitys lieneekin siinä, millaisia uusia ajattelumalleja ja arvoja se toi osaksi suomalaista sosiaali- ja yhteiskuntapolitiikkaa.

60 vuotta teoksen julkaisun jälkeen (sosiaali)poliittisen vaikuttamisen maisema näyttää toisenlaiselta. Hyvinvointivaltiollinen politiikka ajattelutapoineen, sisältöineen, teknologioineen ja välineineen on aiempaa dynaamisempaa, politiikka on taloudellistunut, ja strategisen valtion lainsäädäntötyötä tahdittavat päätöksenteon tueksi perustetut ohjelmat ja hankkeet.Tässä ympäristössä sosiaalipolitiikan kehitystä onkin jähmeiden hyvinvointimallien sijaan ehdotettu hahmotettavaksi sommitelmana, kompleksisina prosesseina, joissa kohtaavat useat paikalliset, kansalliset, ylikansalliset ja välittävät toimijat (Lendvai \& Stubbs 2009; Autto \& Nygård 2015).

Muutoksista riippumatta hyvinvointivaltioon kiinnittyvät ajattelumallit ja arvot puhuttavat edelleen ja sosiaalipoliittiselle asiantuntemukselle on tunnustettua tarvetta. Tätä ilmentää esimerkiksi Sosiaali- ja terveysministeriön asettama ja laajan asiantunti- 
jajoukon vahvistama parlamentaarinen komitea (STM 2021-2027). Sen tehtävänä on valmistella sosiaaliturvauudistusta, joka mahdollistaisi työnteon ja sosiaaliturvan aiempaa paremman yhteensovittamisen muuttuvissa elämäntilanteissa. Sosiaaliturvasta on aikojen saatossa muodostunut monimutkainen tulonsiirtojen ja palveluiden rakennelma, institutionaalisten jatkuvuuksien yhteenliittymä, jonka toimeenpanon paikallisissa sommitelmissa on mukana joukko moninaisia ja potentiaalisesti ristiriitaisia toimijoita. Komiteatyö haastaa asiantuntijat pohtimaan, kuinka sommitelman lukuisat elementit saataisiin jatkossa sovitettua toisiinsa nykyistä paremmin moninaisten ja toisinaan ristiriitaistenkin suuntausten alla.

Sosiaalipoliittisten ilmiöiden monimutkaista suhteisuutta ja verkottuneisuutta on hahmoteltu myös Sosiaalipoliittisen yhdistyksen vuosille 2021-25 laaditussa toimintaohjelmassa. Ohjelmaan, joka Kuusen hengessä sai nimekseen 20-luvun sosiaalipolitiikka, valikoitui kolme toisiinsa kietoutuvaa mutta myös toisistaan erillisinä hahmottuvaa teemaa:Väestörakenne ja sosiaalipolitiikka sukupolvikysymyksenä; Työ ja sosiaaliturva uudessa taloudessa;ja Eriarvoistava aluekehitys. Teemojen kautta voidaan kysyä esimerkiksi mitä tarkoittaa eri sukupolvet huomioiva sosiaalipolitiikka paikallisesti, alueellisesti tai kansallisesti; miten sosiaaliturvauudistus muovaa käsitystä työstä tai työsuhteesta; ja millaisin politiikkatoimin voitaisiin edistää taloudellisesti ja ekologisesti kestävää alue- ja kaupunkikehitystä. Teemat ohjaavat väljästi yhdistyksen vuotuista toiminnan suunnittelua ohjelmakauden aikana. Tänä syksynä 28-29.10. Turussa järjestettävillä Sosiaalipolitiikan päivillä sosiaalipolitiikkaa lähestytään siihen heijastuvien poliittisten jännitteiden kautta. 60-luvun sosiaalipolitiikan merkitystä koskevien pohdintojen tavoin päivien teema 'Hyvinvointivaltio politiikan käänteissä' muistuttaa siitä, kuinka sosiaalipolitiikan kehkeytyminen ja sen sommitelmat ovat aina ajasta ja paikasta riippuvaisten kompromissien tulosta.Yhtenä elementtinä näissä sosiaalipolitiikan menneissä ja tulevissa sommitelmissa Sosiaalipoliittinen yhdistys toivottaakin Januksen lukijat lämpimästi tervetulleiksi mukaan päiville!

Tässä Januksessa ilmestyy neljä artikkelia. Kolme ensimmäistä käsittelevät lapsia koskevia sosiaalipalveluja. Maritta Itäpuisto kollegoineen tarkastelee artikkelissaan perhe- ja lapsityön ammatillisia asiantuntijuuksia kokemusasiantuntijuuden kontekstissa, Tuuli Kalari ja Suvi Raitakari puolestaan lapsen ja sosiaalityöntekijän haastattelukohtaamista lapsiperheiden sosiaalityössä Goffmanin vuorovaikutusjärjestyksen käsitteeseen nojaten. Katarina Groop jäsentää artikkelissaan elämänkulun käännekohtia ja niiden merkitystä lastensuojelun sijaishuollosta aikuistuneiden kokemuksissa. Numeron neljännessä artikkelissa Anna-Leena Riitaoja kumppaneineen tarkastelee, kuinka siirtolaisuuteen kytkeytyvää moninaisuutta tuotetaan sosiaalityön yliopistokoulutuksen ja sosionomi (AMK) -koulutuksen opetussuunnitelmissa. Lisäksi numero sisältää useita mielenkiintoisia puheenvuoroja ja kirja-arvioita.

Helena Hirvonen

dosentti,YTT, Itä-Suomen yliopisto, Sosiaalipoliittisen yhdistyksen puheenjohtaja helena.m.hirvonen@uef.fi 


\section{Kirjallisuus}

Autto, Janne \& Nygård, Mikael (2015) Johdanto: Mitä on hyvinvointivaltion kulttuurintutkimus? Teoksessa Janne Autto \& Mikael Nygård (toim.) Hyvinvointivaltion kulttuurintutkimus. Rovaniemi: Lapin yliopistokustannus, 8-41.

Kuusi, Pekka (1961) 60-luvun sosiaalipolitiikka. Sosiaalipoliittisen yhdistyksen julkaisuja 6. Porvoo \& Helsinki:WSOY

Lendvai, Noémi \& Stubbs, Paul (2009) Assemblages, translation, and intermediaries in South East Europe. Rethinking transnationalism and social policy. European Societies 11 (5), 673-695. https://doi.org/10.1080/14616690802475504

Tuomioja, Erkki (2002) Pekka Kuusi ja 60-luvun sosiaalipolitiikka suunnannäyttäjinä. Janus 10 (4), 308-320.

Riihinen, Olavi (2009) Pekka Kuusesta Terho Pulkkiseen 1957-1969. Teoksessa Risto Jaakkola, Sakari Kainulainen \& Keijo Rahkonen (toim.) Työväensuojelusta sosiaalipolitiikkaan. Sosiaalipoliittinen yhdistys 1908 - 2002. Helsinki: Sosiaalipoliittinen yhdistys, 97-144.

\section{\&}

\section{Yliopistonlehtori, DOSENTTI Ritva LinNAKANGAs 22.11.1964 - 8.6.2021}

Janus-lehden toimituskunnan kuukausikokous 9.6.2021 käynnistyi suru-uutisella. Tuona aamuna työyhteisömme sai tiedon Ritva Linnakankaan menehtymisestä. Ritva piirtyy mieleen tarkkana ja luotettavana työkumppanina sekä huolehtivaisena ja toiset huomioivana ystävänä. Me toimituskunnan jäsenet saimme kokea tuon kumppanuuden ja ystävyyden. Nämä hetket pysykööt mielissämme pitkään.

Janus -lehden toimituskunta 